ofte ikke inn. Resultatet er at selskapene er helt uten sosialt ansvar og med store politiske engasjementer.

Farmasøytisk industri er den mest ekstreme bransjen. Sammen med «helseindustrien» hadde den flest lobbyister i Washington. Disse to brukte over 230 millioner dollar på lobbyister i 2008. Antall lobbyister økte fra 3400 i 1975 til 32890 i 2005 med utgifter på over to milliarder dollar. Forfatterne dokumenterer mange eksempler på resultater fra denne politiske virksomheten, bl.a. mye kriminalitet. Vioxx-medikamentet fra 1999 er et kjent eksempel. Det farmasøytiske selskapet Merck kjente til at Vioxx ga flere letale mageblødninger enn konkurrentenes medikamenter og dessuten kardial overdødelighet. Etter at jukset ble avslørt i 2004, måtte Merck betale hele 4,85 milliarder dollar i erstatninger, men solgte for 2,5 milliarder dollar året før. Sannsynligvis har firmaet tjent på prosjektet.

Den farmasøytiske industriens suksesser er naturlig nok ikke med i denne boken. Viktigere er det at vi får mye dokumentasjon på den tette forbindelsen mellom denne industrien og leger, sykehus, forskere og medisinske fakulteter.

Etter finanskrisen er det mer gangbart enn på lenge å drive selskapene på retrett. Juridiske innskrenkninger nevnes først. Selskapene bør få de samme sosiale forpliktelsene og samme ansvar som de hadde før industrimagnatene overtok amerikansk samfunnsliv tidlig på 1900-tallet. Videre gjennomføres det nå en rekke folkeaksjoner som trekker selskaper for retten, fra en bevegelse som fikk Kellogg fradømt retten til å avertere søte frokostblandinger overfor barn, til store Center for Science in the Public Interest som bl.a. arbeider med å eliminere transfett $\mathrm{i}$ amerikansk mat. Et generelt uttrykk for disse aksjonene er de store sosiale bevegelsene, med Attac i spissen.

Er dette stoffet aktuelt for Norge? Norske selskaper har mange sosiale forpliktelser, og lovgivingen er ikke så markant liberalistisk som den amerikanske, men utviklingen går i den retningen. Antakelig er det viktigere at norske selskaper er for små, kanskje med unntak av Statoil og Telenor, og at de ikke er grundig undersøkt. En historisk studie av Statoil viser hvilken arena den internasjonale delen av selskapet opererer på (1). Studien kan bare dokumentere litt kriminalitet, den kjente korrupsjonen i Libya, men sannsynligvis må Statoil betale «signaturbonuser» til korrupte ledere når selskapet konkurrerer ute med de store.

Dette er i alle fall en lærerik bok om dagens viktige selskaper i verden. Den anbefales særlig til dem som er interessert i den farmasøytiske industrien.
Litteratur

1. Ryggvik H. Til siste dråpe: om oljens politiske økonomi. Oslo: Aschehoug, 2009

\section{Cellekultur og etisk ukultur}

Skloot R.

The immortal life of Henrietta Lacks

369 s, ill. New York: Crown Publishers, 2010.

Pris USD 26

ISBN 978-1-4000-5217-2

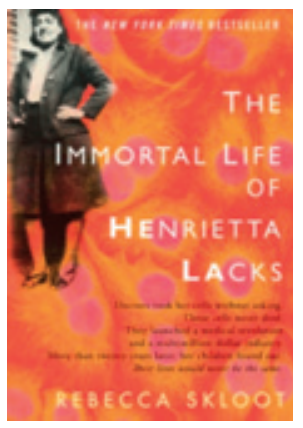

The immortal life of Henrietta Lacks, som kom ut i januar 2010, vakte umiddelbart stor oppmerksomhet (1). Henrietta Lacks er kvinnen som ga navn og opphav til de såkalte HeLa-cellene - en cellelinje som har hatt grunnleggende betydning i medisinen (2). Et PubMed-søk gir over 63000 treff på «hela cells», og alle cellene som er produsert, veier 100 ganger mer enn Empire State Building.

I lettlest, fengende prosa presenterer man tre ulike fortellinger. Den sentrale er historien om Henrietta Lacks, en farget fembarnsmor som døde av livmorhalskreft i 1951, åtte måneder etter at diagnosen var stilt og mindre enn et år etter hennes siste fødsel. Hun ble 31 år. Denne delen handler i stor grad om forskjeller i rase, sosial klasse og utdanning. Mangelen på åpenhet, respekt og alminnelig høflighet avsløres, og det kommer til syne en avgrunn i forholdet mellom den medisinske eliten og forskersamfunnet på den ene siden og pasientrettigheter vi i dag tar for gitt, på den andre siden. Innbakt $\mathrm{i}$ dette får leseren presentert den rivende utviklingen i cellebiologien de siste 50-60 årene og som utgjør fundamentet for forståelsen og utøvelsen av dagens medisinske praksis. Ingen cellelinje var så potent og så potensielt problematisk som HeLa. Sistnevnte gjaldt i stor grad den reelle faren for forurensning av andre cellelinjer.

Bokens tredje retning berører eierskapet til humane celler og biologisk materiale som er fjernet ved operasjon eller annen medisinsk behandling. Problemet oppstår når slikt materiale blir gjenstand for forskning og omsettes mot økonomisk eller annen godtgjøring. Her er det duket for interessemotsetninger. Representanter for forskersamfunnet vil kunne hevde at HeLa-cellene ikke var oppfunnet eller oppdaget av Henrietta Lacks, og at verken hun eller familien har noen rettigheter eller innflytelse på bruken av dem. Men det er heller ingen tvil om at det materialet det er snakk om, betraktes og behandles som en knapphetsressurs, og omsettes i et marked for rede penger. Er da de som foredler og forvalter ressursene i større grad enn råvareleverandøren berettiget en økonomisk gevinst knyttet til omsetningen? Hørte jeg laks og olje?

Familiens frustrasjon over mangelen på informasjon og kravet om å få del i et økonomisk utbytte kommer gjentatte ganger til overflaten. Der slike spørsmål har vært behandlet i amerikanske domstoler, har avgjørelsen vanligvis gått i forskernes favør, men siste ord er neppe sagt. Likevel har disse motsetningene medvirket til å fremme utviklingen rundt spørsmål som autonomi, medvirkning og informert samtykke knyttet til både medisinsk utredning, behandling og forskning. Utviklingen av fagområdet medisinsk forskningsetikk og de forskningsetiske komiteene kan kalles ektefødte barn av HeLa-cellenes historie.

Enhver vil ha utbytte av å lese boken, men i første rekke alle som er opptatt av medisinsk historie, basalforskning, klinisk forskning og forskningsetikk. Undervisere og veiledere bør anbefale den til studenter og stipendiater og diskutere etiske utfordringer og dilemmaer i skjæringspunktet mellom individ og samfunn. Ingen kan forbli uberørt av å lese om skjebnen til Henrietta Lacks og hennes familie.

Geir W. Jacobsen

Institutt for samfunnsmedisin

Norges teknisk-naturvitenskapelige universitet

Litteratur

1. Grady D. A lasting gift to medicine that wasn' really a gift. New York Times 2.2.2010 www. nytimes.com/2010/02/02/health/02seco.html?_r= (2.8.2010).

2. HeLa cells by Radiolab. http://vimeo.com/9581140 (2.8.2010).

\section{Ambisiøst verk om musikalitet og kommunikasjon}

Malloch S, Trevarthen C, red.

Communicative musicality

Exploring the basis of human companionship. 627 s, tab, ill. Oxford: Oxford University Press, 2010. Pris: GBP 30

ISBN 978-0-19-856628-1

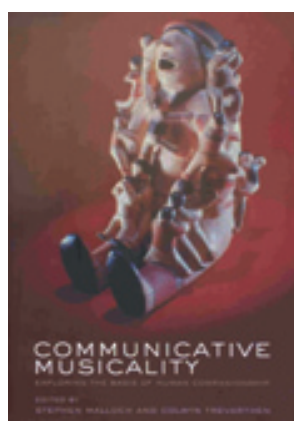

Colwyn Trevarthen har gjennom flere tiår satt spor gjennom sin forskning på spedbarn og kommunikasjon, bl.a. gjennom begrepene intrinsic motive pulse og turntaking som uttrykk for grunnleggende proses- 